\title{
Future Trends of Data Mining in Predicting the Various Diseases in Medical Healthcare System
}

\author{
Shubpreet Kaur $^{1}$ and Dr. R.K.Bawa ${ }^{2}$ \\ ${ }^{1}$ Punjabi University, Patiala, Punjab \\ ${ }^{2}$ Punjabi University,Patiala, Punjab \\ shubpreetkaur@gmail.com,rajesh.k.bawa@gmail.com
}

\begin{abstract}
The thriving medical applications of data mining in the fields of medicine and public health has led to the popularity of its use in knowledge discovery in databases (KDD). Data mining has revealed novel biomedical and healthcare acquaintances for clinical decision making that has great potential to improve the treatment quality of hospitals and increase the survival rate of patients. Disease diagnosis is one of the applications where data mining tools are establishing the successful results. Data mining intends to endow with a systematic survey of current techniques of knowledge discovery in databases using data mining techniques that are in use in today's medical research. Discussion is made to enable the disease diagnosis and the breakthrough of hidden healthcare patterns from related databases is offered. Also, the use of data mining to discover such relationships as those between health conditions and a disease is presented. It further discusses about the tools that can be used for the processing and classification of data. This paper summarizes various technical articles on medical diagnosis and prognosis. It has also been focused on current research being carried out using the data mining techniques to enhance the disease (s) forecasting process. This research paper provides future trends of current techniques of KDD, using data mining tools for healthcare. It also confers significant issues and challenges associated with data mining and healthcare in general. The research found a growing number of data mining applications, including analysis of health care centers for better health policy-making, detection of disease outbreaks and preventable hospital deaths. The root causes of all diseases get closer towards drugs i.e. the foremost risk factor of all hilarious diseases. Drug addiction using WEKA has been used that brings into light concerning majority of drug abusers started abusing drugs at age below 20yrs.It is to make aware the druggist about the various diseases that are caused with heavy or long term intake of drugs in their life. So, to make an expert system that will awake the youth about precarious use of drugs and also alert the affected person.
\end{abstract}

Keywords: Data Mining Techniques, Data Mining Tools, Data Mining Models, Healthcare, Medical Diseases, Drug Abuse.

\section{Introduction and Motivation}

Data mining is the extraction of hidden predictive information and unknown data, patterns, relationships and knowledge by exploring the large data sets which are difficult to find and detect with traditional statistical methods. Data mining it is powerful technology which will discover most important information from the data warehouse of the organizations. It is a very crucial step that collectively examine large amount of routinely data. To find latest patterns in healthcare industry, there exist various interactive and scalable data mining methods. Data mining is a quantitative approach which is user friendly in reading reports and reducing errors and controls the quality more uniformly. Important task of data mining is data pre-processing. 
Data mining tools are used for decision making. Prediction and classification techniques are used in which classification technique predicts the unknown values with respect to generated model. An assortment of data mining techniques can be applied to find associations and regularities in data, extract knowledge in the forms of rules and predict the value of the dependent variables. Common data mining techniques which are used in almost all the sectors are listed as: Naive Bayes, Decision Tree, Artificial neural network (ANN), Bagging algorithm, K- nearest neighborhood (KNN), Support vector machine (SVM) etc. Data mining is an important step of knowledge discovery in databases (KDD) which is an iterative process of data cleaning, integration of data, data selection, pattern recognition and data mining knowledge recognition. KDD and data mining are also used interchangeably. Data mining encompasses association, classification, clustering, statistical analysis and prediction.

Data mining has been widely used in areas of communication, credit assessment, stock market prediction, marketing, banking, education, health and medicine, hazard forecasting, knowledge acquisition, scientific discovery, fraud detection, etc but data mining holds significant presence in every field of medical for the diagnosis of several diseases such as diabetes, skin cancer, lung cancer, breast cancer, heart disease, kidney failure, kidney stone, liver disorder, hepatitis etc. Data mining applications include analysis of data for better policy making in health, prevention of various errors in hospitals, detection of fraudulent insurance claims early detection and prevention of various diseases, value for more money, saving costs and saving more lives by reducing death rates.

Drug is any substance that when taken into a living organism may modify one or more of its functions. Drugs can provide temporary relief from unhealthy symptoms and/or permanently supply the body with necessary substances the body can no longer make. Some drugs lead to an unhealthy dependency that has both physiological and behavioral roots. Drug addiction can cause serious, long-term consequences, including problems with physical and mental health, relationships, employment, and the law [3]. Adolescence is typically a period of experimentation, irrespective of parenting skills and influence. However, the more likely threat to any teenager's health is the use of drugs such as alcohol and tobacco.

\section{Related Work}

Automated medical diagnosis helps the doctors to calculate the correct disease with less time. Table 1 highlights the foremost objectives of the authors working in the field of predicting medical disease(s) using data mining methodology. Knowledge gained by exercising of aim(s) of data mining can be used to make booming decisions that will improve success of healthcare organization and health of the patients.

Table 1. Objective(s) of Related Work Done by Number on Medical Diseases

\begin{tabular}{|l|l|l|l|}
\hline Author & $\begin{array}{l}\text { Year of } \\
\text { Publication }\end{array}$ & $\begin{array}{l}\text { Disease } \\
\text { Considered }\end{array}$ & Objectives \\
\hline $\begin{array}{l}\text { Dursun Delen et al [3], } \\
\text { Bellaachia et al [4] }\end{array}$ & 2005,2006 & Breast cancer & $\begin{array}{l}\text { Analysis of the prediction of breast cancer } \\
\text { survivability data mining methods. }\end{array}$ \\
\hline Asha Rajkumar et al [9] & 2010 & Heart Disease & $\begin{array}{l}\text { To achieve high accuracy by classifying } \\
\text { algorithms }\end{array}$ \\
\hline $\begin{array}{l}\text { D.Senthil Kumar et al } \\
\text { [16] }\end{array}$ & 2011 & $\begin{array}{l}\text { Diabetes, } \\
\text { Heart, } \\
\text { Hepatitis }\end{array}$ & $\begin{array}{l}\text { Development and evaluation of a clinical } \\
\text { decision support system for the treatment of } \\
\text { patients with heart disease, diabetes and } \\
\text { hepatitis. }\end{array}$ \\
\hline Jyoti Soni [22] & 2011 & Heart Disease & $\begin{array}{l}\text { Predictive data mining for medical } \\
\text { diagnosis: An overview of heart disease }\end{array}$ \\
\hline
\end{tabular}




\begin{tabular}{|l|l|l|l|}
\hline & & & prediction \\
\hline Akhil jabbar et al [11] & 2012 & Heart Disease & $\begin{array}{l}\text { Proposed a system for heart disease } \\
\text { prediction using data mining techniques }\end{array}$ \\
\hline $\begin{array}{l}\text { DSVGK Kaladhar et al } \\
\text { [19] }\end{array}$ & 2012 & Kidney Stone & $\begin{array}{l}\text { Statistical and data mining aspects on } \\
\text { kidney stones: a systematic review and } \\
\text { meta analysis }\end{array}$ \\
\hline Mai Shouman [12] & 2012 & Heart Disease & $\begin{array}{l}\text { Applying K-nearest neighbor in diagnosing } \\
\text { heart disease patients }\end{array}$ \\
\hline Abhishek Taneja [13] & 2013 & Heart Disease & $\begin{array}{l}\text { To design a predictive model for heart } \\
\text { disease detection to enhance their liability } \\
\text { of heart disease diagnosis. }\end{array}$ \\
\hline $\begin{array}{l}\text { Kawsar Ahmed et al } \\
\text { [7],[23] }\end{array}$ & 2013 & $\begin{array}{l}\text { Lung Cancer, } \\
\text { Skin Cancer }\end{array}$ & $\begin{array}{l}\text { Early prevention and detection of skin } \\
\text { cancer and lung cancer risk using data } \\
\text { mining }\end{array}$ \\
\hline $\begin{array}{l}\text { Syeda Farha Shazmeen } \\
\text { et al [21] }\end{array}$ & 2013 & Liver Disorder & $\begin{array}{l}\text { Performance evaluation of different data } \\
\text { mining classification algorithm and } \\
\text { predictive analysis }\end{array}$ \\
\hline V. Krishnaiah et al [8] & 2013 & Lung Cancer & $\begin{array}{l}\text { Diagnosis of lung cancer prediction system } \\
\text { using data mining classification techniques }\end{array}$ \\
\hline $\begin{array}{l}\text { Vikram Kumar Gupta et } \\
\text { al [18] }\end{array}$ & 2013 & $\begin{array}{l}\text { Drug } \\
\text { Addiction }\end{array}$ & $\begin{array}{l}\text { A study of profile of patients admitted in } \\
\text { the drug de-addiction centers in the state of } \\
\text { Punjab }\end{array}$ \\
\hline K R Lakshmi et al [20] & 2014 & $\begin{array}{l}\text { Kidney } \\
\text { dialysis }\end{array}$ & $\begin{array}{l}\text { Performance comparison of three data } \\
\text { mining techniques for predicting kidney } \\
\text { dialysis survivability }\end{array}$ \\
\hline
\end{tabular}

Ample of research is done on drugs and its ill effects. Bounty of surveys is available. But no expert system or such effort is seen to have control over drugs. The objectives of work done on drug abusers in past are displayed in Table 2.

Table 2. Objective(s) of Related Work Done by Number on Drug Abuse

\begin{tabular}{|c|c|c|}
\hline Author & Year & Objective(s) \\
\hline Anc & 2000 & $\begin{array}{l}\text { Examination of the effects of acculturation and acculturative } \\
\text { stress on the intensity of alcohol involvement during middle } \\
\text { school among Latino adolescents. }\end{array}$ \\
\hline Brian Bors & 2008 & $\begin{array}{l}\text { Aim to increase the knowledge of drinking norms on college } \\
\text { campuses. }\end{array}$ \\
\hline $\begin{array}{l}\text { Isaac C. Rhew et al } \\
{[20]}\end{array}$ & 11 & texts \\
\hline Angelina et al [27] & 2013 & e and predictors \\
\hline $\begin{array}{l}\text { Naresh Nebhinani et al } \\
\text { [24] }\end{array}$ & 2013 & $\begin{array}{l}\text { Aim to study the demographic and clinical profile of women } \\
\text { seeking de addiction treatment at a tertiary care center in North } \\
\text { India. }\end{array}$ \\
\hline Tas & 2014 & $\begin{array}{l}\text { Long-term effect of lowering the minimum purchase age for } \\
\text { alcohol from age } 20 \text { to age } 18 \text { years on alcohol-involved crashes } \\
\text { in New Zealand. }\end{array}$ \\
\hline Eduardo et al [31] & 2014 & $\begin{array}{l}\text { The objective of the present study was to examine brain activity } \\
\text { during execution and inhibition in young binge drinkers in } \\
\text { relation to the progression of their drinking habits response over } \\
\text { time. }\end{array}$ \\
\hline
\end{tabular}




\section{Research Objectives and Questions}

This study is aimed at uncovering and analyzing a range of data mining tools and techniques for optimally predicting the numerous medical diseases to endow the healthcare section with high competence and more effectiveness. In achieving the research objectives, this study intends to answer the following five questions:

(i) Does data mining really provide an efficient way to extract the required clinical information from voluminous, raw and heterogeneous data?

(ii) Are there any promising techniques to predict and forecast the medical diseases with high accuracy and low cost?

(iii) What are the various issues and challenges in data mining as applied to the medical practice?

(iv) What are the plausible benefits of this research in relation with substance abuse?

(v) How can we simultaneously retrieve the information and minimize the efforts of an expert system for other clinical concerns like drug addiction?

\section{Use of Data Mining in Medical}

Today is the era of data mining where prediction of variety of disease is enduring procedure. Data mining has proved with flourished results in medical. But such work is seen in direction to control over drugs usage. Data mining has plenty of techniques and tools available.

\subsection{Comparison of Distinct Data Mining Techniques}

Different types of mining algorithms in the healthcare field have been proposed by different researchers in recent years. A particular algorithm may not be applied to all the applications due to complexity for appropriate data types of the algorithm. Consequently the choice of an acceptable data mining algorithm depends on not only the purpose of an application, but also on the compatibility of the data set. Table 3 presents the comparative analysis of different data mining techniques and algorithms which have been used by most of the researchers in medical data mining.

Table 3. Comparison of Distinct Data Mining Techniques

\begin{tabular}{|l|l|l|l|l|l|l|l|l|}
\hline Author Name & Year & \multicolumn{9}{|l|}{ Data Mining Techniques } \\
\hline & & $\begin{array}{l}\text { AN } \\
\text { N }\end{array}$ & $\begin{array}{l}\text { DTree } \\
\text { s }\end{array}$ & $\begin{array}{l}\text { Logistic } \\
\text { Regressi } \\
\text { on }\end{array}$ & $\begin{array}{l}\text { KN } \\
\text { N }\end{array}$ & $\begin{array}{l}\text { N } \\
\text { B }\end{array}$ & $\begin{array}{l}\text { SV } \\
\text { M }\end{array}$ & Other \\
\hline $\begin{array}{l}\text { Dursun Delen et } \\
\text { al [3] }\end{array}$ & 2005 & $\sqrt{ }$ & $\sqrt{ }$ & $\sqrt{ }$ & $\times$ & $\times$ & $\times$ & - \\
\hline $\begin{array}{l}\text { Bellaachia et al } \\
\text { [4] }\end{array}$ & 2006 & $\sqrt{ }$ & $\sqrt{ }$ & $\times$ & $\times$ & $\sqrt{ }$ & $\times$ & - \\
\hline $\begin{array}{l}\text { Asha Rajkumar } \\
\text { et al [9] }\end{array}$ & 2010 & $\times$ & $\sqrt{ }$ & $\times$ & $\sqrt{ }$ & $\sqrt{ }$ & $\times$ & - \\
\hline $\begin{array}{l}\text { D.Senthil Kumar } \\
\text { [16] }\end{array}$ & 2011 & $\times$ & $\sqrt{ }$ & $\times$ & $\times$ & $\times$ & $\times$ & - \\
\hline Jyoti Soni [22] & 2011 & $\sqrt{ }$ & $\sqrt{ }$ & $\times$ & $\sqrt{ }$ & $\sqrt{ }$ & $\times$ & - \\
\hline $\begin{array}{l}\text { Akhil jabbar et al } \\
\text { [11] }\end{array}$ & 2012 & $\sqrt{ }$ & $\sqrt{ }$ & $\times$ & $\times$ & $\sqrt{ }$ & $\times$ & - \\
\hline $\begin{array}{l}\text { DSVGK } \\
\text { Kaladhar et al } \\
{[19]}\end{array}$ & 2012 & $\times$ & $\sqrt{ }$ & $\times$ & $\sqrt{ }$ & $\sqrt{ }$ & $\sqrt{ }$ & $\begin{array}{l}\text { Random } \\
\text { Forest, } \\
\text { Bagging } \\
\text { Algorithm }\end{array}$ \\
\hline
\end{tabular}




\begin{tabular}{|c|c|c|c|c|c|c|c|c|}
\hline $\begin{array}{ll}\text { Mai } & \text { Shouman } \\
{[12]} & \\
\end{array}$ & 2012 & $x$ & $x$ & $x$ & $\sqrt{ }$ & $x$ & $x$ & - \\
\hline $\begin{array}{l}\text { Abhishek Taneja } \\
\text { [13] }\end{array}$ & 2013 & $\sqrt{ }$ & $\sqrt{ }$ & $x$ & $x$ & $\sqrt{ }$ & $x$ & - \\
\hline $\begin{array}{l}\text { Kawsar Ahmed } \\
\text { et al [23] }\end{array}$ & 2013 & $x$ & $x$ & $x$ & $x$ & $x$ & $x$ & Mafia \\
\hline $\begin{array}{ll}\text { Kawsar } & \text { Ahmed } \\
\text { et al [7] } & \\
\end{array}$ & 2013 & $x$ & $\sqrt{ }$ & $x$ & $x$ & $x$ & $x$ & $\begin{array}{l}\text { Apriori } \\
\text { Algorithm }\end{array}$ \\
\hline $\begin{array}{ll}\text { Syeda } & \text { Farha } \\
\text { Shazmeen } & \text { et al } \\
{[21]} & \\
{[21}\end{array}$ & 2013 & $\sqrt{ }$ & $\sqrt{ }$ & $x$ & $\sqrt{ }$ & $\sqrt{ }$ & $\sqrt{ }$ & - \\
\hline $\begin{array}{l}\text { K R Lakshmi et } \\
\text { al. [20] }\end{array}$ & 2014 & $\sqrt{ }$ & $\sqrt{ }$ & $\sqrt{ }$ & $x$ & $x$ & $x$ & - \\
\hline
\end{tabular}

\subsection{Comparative Analysis of Data Mining Tools}

Due to the extensive use and intricacy involved in building data mining applications, a large number of data mining tools have been developed over the decades. Different tools use diverse algorithm base and techniques to carry out data mining tasks. Every tool has its own advantages and disadvantages. Numerous functionalities offered by these tools incorporate:

- characterization and classification of data,

- patterns evaluation,

- $\quad$ associations and correlations,

- $\quad$ prediction over the data

The maturity and relevance of data mining algorithms necessitates the utilization of influential software tools. As the number of accessible tools continues to develop, the preference of the most suitable tool becomes increasingly tricky. Consequently, a number of authors have suggested and/or used the multiplicity of data mining tools as presented in Table 4.

Table 4. Comparison of Different Used Data Mining Tools

\begin{tabular}{|l|l|l|l|l|l|l|l|}
\hline Author Name & Year & \multicolumn{6}{ll}{ Tool Used } \\
\hline & & Weka & $\begin{array}{l}\text { Tanagr } \\
\text { a }\end{array}$ & $\begin{array}{l}\text { Orang } \\
\text { e }\end{array}$ & R & $\begin{array}{l}\text { Rapid } \\
\text { Miner }\end{array}$ & Knime \\
\hline Bellaachia et al [4] & 2006 & $\sqrt{ }$ & $\times$ & $\times$ & $\times$ & $\times$ & $\times$ \\
\hline Asha Rajkumar et al [9] & 2010 & $\times$ & $\sqrt{ }$ & $\times$ & $\times$ & $\times$ & $\times$ \\
\hline D. Senthil Kumar [16] & 2011 & $\sqrt{ }$ & $\times$ & $\times$ & $\times$ & $\times$ & $\times$ \\
\hline Jyoti Soni [22] & 2011 & $\sqrt{ }$ & $\times$ & $\times$ & $\times$ & $\times$ & $\times$ \\
\hline $\begin{array}{l}\text { DSVGK Kaladhar et al } \\
\text { [19] }\end{array}$ & 2012 & $\sqrt{ }$ & $\times$ & $\sqrt{ }$ & $\times$ & $\times$ & $\times$ \\
\hline $\begin{array}{l}\text { Syeda Farha Shazmeen } \\
\text { et al [21] }\end{array}$ & 2013 & $\sqrt{ }$ & $\times$ & $\times$ & $\times$ & $\sqrt{ }$ & $\times$ \\
\hline K R Lakshmi et al [20] & 2014 & $\times$ & $\sqrt{ }$ & $\times$ & $\times$ & $\times$ & $\times$ \\
\hline
\end{tabular}

Table 4 illustrates that mostly the tool used by various authors is Weka. Data mining tools foretell the future trends and behaviors that permit the businesses to formulate positive and knowledge-driven decisions. Data mining tools can respond to the business issues that were time consuming to resolve traditionally. 
An assortment of surveys and research had been conducted over the utilization of the most popular tool among the organizations. Table 5 represents a wide range of parameters based upon which, a variety of renowned data mining tools have been compared.

Table 5. Description of Numerous Parameters with Respect to Various Data Mining Tools

\begin{tabular}{|c|c|c|c|c|c|c|}
\hline Tools $\quad \rightarrow$ & Weka & Orange & $\mathrm{R}$ & Knime & $\begin{array}{l}\text { Rapid } \\
\text { Miner }\end{array}$ & $\begin{array}{l}\text { Tanagr } \\
\mathrm{a}\end{array}$ \\
\hline \multicolumn{7}{|l|}{ Parameters $\quad \downarrow$} \\
\hline $\begin{array}{l}\text { Ability to Partition } \\
\text { the Datasets }\end{array}$ & Limited & Limited & Limited & Limited & Limited & Limited \\
\hline $\begin{array}{l}\text { Ability to Cross } \\
\text { Validate the Model }\end{array}$ & Limited & Limited & Full & Limited & Full & No \\
\hline $\begin{array}{l}\text { Analysis and } \\
\text { Processing } \\
\text { Capability }\end{array}$ & Yes & Yes & Yes & Yes & Yes & Yes \\
\hline $\begin{array}{l}\text { Association Rule } \\
\text { Support }\end{array}$ & Yes & Yes & Yes & Yes & Yes & Yes \\
\hline $\begin{array}{l}\text { Bayes Network } \\
\text { Approach }\end{array}$ & Yes & Yes & No & Yes & Yes & Yes \\
\hline $\begin{array}{l}\text { Clustering } \\
\text { Approach }\end{array}$ & Yes & Yes & Yes & Yes & Yes & Yes \\
\hline $\begin{array}{l}\text { Database System } \\
\text { Support }\end{array}$ & Yes & No & Yes & Yes & Yes & No \\
\hline $\begin{array}{ll}\text { Decision } & \text { Tree } \\
\text { Approach } & \end{array}$ & Yes & Yes & Yes & Yes & Yes & Yes \\
\hline $\begin{array}{l}\text { Descriptor } \\
\text { Selection Facility }\end{array}$ & Yes & No & No & No & Yes & Yes \\
\hline $\begin{array}{l}\text { Descriptor Scaling } \\
\text { Facility }\end{array}$ & No & No & No & Yes & Yes & No \\
\hline Ease of Learning & Better & Best & Better & Better & Good & Good \\
\hline Evaluation Ability & Yes & Yes & Yes & Yes & Yes & Yes \\
\hline Feature Selection & Yes & No & No & Yes & Yes & Yes \\
\hline $\begin{array}{l}\text { Graphical } \\
\text { Representation }\end{array}$ & Limited & Limited & Limited & Full & Limited & Limited \\
\hline Interface & $\begin{array}{l}\text { Graphica } \\
\text { 1/ } \\
\text { Comman } \\
\text { d Line }\end{array}$ & $\begin{array}{l}\text { Graphical } \\
\text { / } \\
\text { Comman } \\
\text { d } \\
\text { Line }\end{array}$ & $\begin{array}{l}\text { Graphica } \\
\text { 1/ } \\
\text { Comman } \\
\text { d Line }\end{array}$ & $\begin{array}{l}\text { Graphic } \\
\text { al }\end{array}$ & Graphical & $\begin{array}{l}\text { Graphi } \\
\text { cal }\end{array}$ \\
\hline License & Open & Open & Open & Open & Open & Open \\
\hline Major Users & $\begin{array}{l}\text { Academi } \\
\text { cs/ } \\
\text { Industry }\end{array}$ & $\begin{array}{l}\text { Academic } \\
\text { s/ } \\
\text { Industry/ } \\
\text { Testing/ } \\
\text { Bioinfor } \\
\text { matics }\end{array}$ & $\begin{array}{l}\text { Academi } \\
\mathrm{cs} / \\
\text { Industry }\end{array}$ & $\begin{array}{l}\text { Academ } \\
\text { ics/ } \\
\text { Industry }\end{array}$ & $\begin{array}{l}\text { Marketin } \\
\text { g/ } \\
\text { Sales/ } \\
\text { Manufact } \\
\text { uring/ } \\
\text { Telecom }\end{array}$ & $\begin{array}{l}\text { Researc } \\
\mathrm{h}\end{array}$ \\
\hline $\begin{array}{ll}\text { Neural Network } \\
\text { Approach }\end{array}$ & Yes & No & No & Yes & Yes & Yes \\
\hline
\end{tabular}




\begin{tabular}{|l|l|l|l|l|l|l|}
\hline & $\begin{array}{l}\text { Linux/ } \\
\text { Window } \\
\text { S/ }\end{array}$ & $\begin{array}{l}\text { Linux/ } \\
\text { Windows } \\
\text { Support }\end{array}$ & $\begin{array}{l}\text { Unix/ } \\
\text { Window } \\
\text { s/ System } \\
\text { Sac }\end{array}$ & $\begin{array}{l}\text { Linux/ } \\
\text { Window } \\
\text { s/ } \\
\text { Mac }\end{array}$ & $\begin{array}{l}\text { Linux/ } \\
\text { Windows } \\
\text { / }\end{array}$ & Mac \\
\hline $\begin{array}{l}\text { Parameter } \\
\text { Optimization }\end{array}$ & No & No & Yes & No & Yes & No \\
\hline $\begin{array}{l}\text { Programming } \\
\text { Language }\end{array}$ & Java & $\begin{array}{l}\text { C++, } \\
\text { Python }\end{array}$ & $\begin{array}{l}\text { Fortran, } \\
\text { R }\end{array}$ & Java & Java & HTML \\
\hline SVM Approach & Yes & Yes & Yes & Yes & Yes & Yes \\
\hline Usability & Better & Best & Best & Better & Best & Good \\
\hline
\end{tabular}

\section{Data Sets used in Medical}

Below table 6 depicts various databases used with respect to unsafe diseases. Different authors have used various datasets available online or from some hospitals or respective centers. But for drug abusers, no data sets are available online nor are they available at hospitals. It needs interview each patient individually at drug addiction centers.

Table 6. Databases used with Respect to Treacherous Diseases

\begin{tabular}{|l|l|l|}
\hline \multicolumn{1}{|c|}{ Author } & \multicolumn{1}{c|}{ Disease Considered } & \multicolumn{1}{c|}{ Data Set/Database Used } \\
\hline Dursun Delen et al [3], Bellaachia et al [4] & Breast cancer & SEER cancer incidence database \\
\hline Jyoti Soni [22], Mai Shouman[12] & Heart & Cleveland heart disease database \\
\hline Akhil jabbar et al [11] & heart & UCl machine Learning repository \\
\hline Kawsar Ahmed et al [23][7] & Lung cancer, skin Cancer & Different diagnostic centres \\
\hline Abhishek Taneja [13] & Heart & PGl, chd \\
\hline D.Senthil Kumar et al [16] & Heart, Diabetes, Hepaititis & $\begin{array}{l}\text { UC-Irvine archieve of machine } \\
\text { learning repository }\end{array}$ \\
\hline K R Lakshmi et al [20] & Kidney dialysis & $\begin{array}{l}\text { Hasheminejad kidney centre of } \\
\text { Tehran }\end{array}$ \\
\hline Syeda Farha Shazmeen et al [21] & Liver Disorder & Fisher's IRIS dataset \\
\hline V. Krishnaiah et al.[8] & Lung Cancer & UC1 repository \\
\hline
\end{tabular}

\section{Performance Evaluation Measures}

Performance is measured using WEKA; an open source machine learning software which gives the output in terms of TP, TN, FP, and FN. Accuracy is interpreted from the given formula.

Accuracy $=\frac{\mathrm{TP}+\mathrm{TN}}{\mathrm{TP}+\mathrm{FP}+\mathrm{TN}+\mathrm{FN}}$

Where TP, TN stands for True Positive and True Negative and FP, FN stands for False Positive and False Negative. TP+TN signify percentage of correctly classified instances and $\mathrm{TP}+\mathrm{FP}+\mathrm{TN}+\mathrm{FN}$ signifies total of correctly and incorrectly classified instances. 


\section{Analysis of Accuracies in Medical}

Below are accuracies shown applied on various diseases using different data mining techniques. Accuracy is then computed from the above formula to find the no. of affected cases with respect to values in given parameters. Commonly used techniques are Decision trees (Dtrees), Artificial Neural Network (ANN), Naïve Bayes (NB). The Comparison of these techniques used year wise on different disease is analyzed. Table 7 shows the comparison of various diseases on ANN. No such work is done in drug abusers.

Table 7. Accuracies Applied on Artificial Neural Networks

\begin{tabular}{|l|l|l|c|}
\hline Disease Considered & Author of Publication & Year of Publication & Accuracy in ANN \\
\hline Breast Cancer & Dursun Delen et al. & 2005 & $91.21 \%$ \\
\hline Heart & Andreeva, P & 2006 & $82.77 \%$ \\
\hline Breast Cancer & Bellaachia et al & 2006 & $86.50 \%$ \\
\hline Heart & Palaniappan, et al. & 2007 & $93.54 \%$ \\
\hline Heart & De Beule, et al. & 2007 & $82.00 \%$ \\
\hline Heart & Tantimongcolwata,et al. & 2008 & $74.50 \%$ \\
\hline Heart & Hara, et al. & 2008 & $82.30 \%$ \\
\hline Heart & Akhil jabbar et al & 2012 & $82.00 \%$ \\
\hline Heart & Abhishek Taneja & 2013 & $93.83 \%$ \\
\hline Liver & Syeda Farha Shazmeen et al & 2013 & $67.59 \%$ \\
\hline Kidney & K R Lakshmi et al. & 2014 & $93.85 \%$ \\
\hline
\end{tabular}

Table 6 shows maximum accuracy of $93.85 \%$ of kidney. More diseases are coming to research to find the chance with high accuracy of prediction of risky diseases. Figure 1 shows the graph of accuracies with range of percentage to diseases.

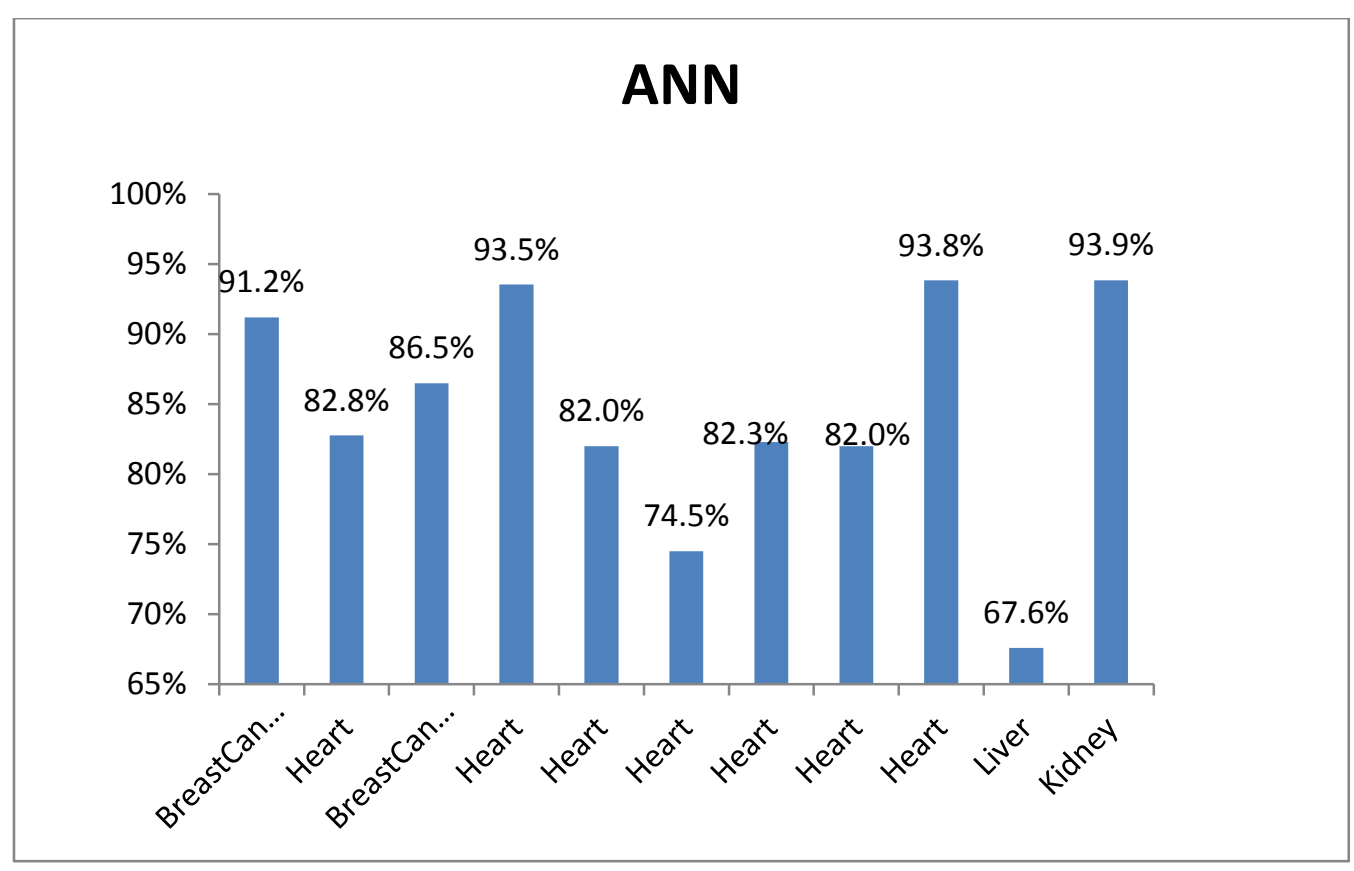

Figure 1. Comparison of Various Diseases on ANN Technique 
ANN shows the maximum accuracy of $93.9 \%$ and minimum accuracy of $67.6 \%$. Table 7 shows the comparison of various diseases on Dtrees.

Table 7. Accuracy Measure in Decision Trees

\begin{tabular}{|l|l|c|c|}
\hline Disease Considered & \multicolumn{1}{|c|}{ Author } & Year of Publication & Accuracies in DTrees \\
\hline Heart & Cheung, & 2001 & $81.11 \%$ \\
\hline Skin Diseases & Bojarczuk & 2001 & $89.12 \%$ \\
\hline Breast Cancer & Dursun Delen et al. & 2005 & $93.62 \%$ \\
\hline Heart & Andreeva, P & 2006 & $75.73 \%$ \\
\hline Breast Cancer & Bellaachia et al & 2006 & $86.70 \%$ \\
\hline Heart & Palaniappan, et al. & 2007 & $94.93 \%$ \\
\hline Heart & Sitar-Taut et al. & 2009 & $60.40 \%$ \\
\hline Heart & Tu, et al., & 2009 & $78.90 \%$ \\
\hline Skin Diseases & Polat and Gunes & 2009 & $96.71 \%$ \\
\hline Heart & Asha Rajkumar et al & 2010 & $52.00 \%$ \\
\hline Heart & Jyoti Soni & 2011 & $99.20 \%$ \\
\hline Heart & Akhil jabbar et al & 2012 & $80.00 \%$ \\
\hline Heart & Abhishek Taneja & 2013 & $94.29 \%$ \\
\hline Liver & Syeda Farha Shazmeen et al. & 2013 & $69.58 \%$ \\
\hline Kidney & K R Lakshmi et al. & 2014 & $78.44 \%$ \\
\hline
\end{tabular}

The main objective is to achieve the maximum accuracy among hazardous diseases. Dtrees are most popular data mining technique that is applied and used everywhere and gives maximum optimal results. Figure 2 shows graph of Dtrees used in various medical diseases.

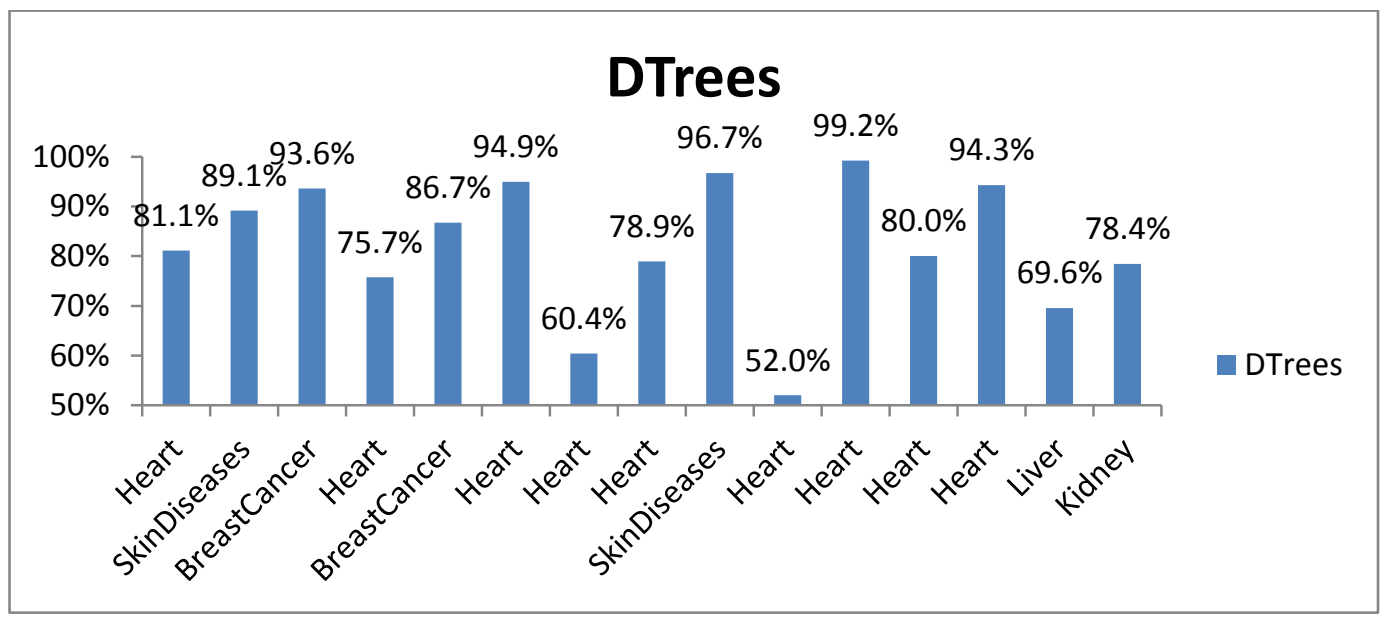

Figure 2. Comparison of various diseases on Dtrees technique

Decision tree is the most popular technique and it has given the maximum accuracy of $99.2 \%$. Table 8 shows the comparison of various diseases on Naïve Bayes. 
Table 8. Accuracy Measure in Naïve Bayes

\begin{tabular}{|l|l|l|c|}
\hline Disease Considered & \multicolumn{1}{|c|}{ Author } & Year of Publication & Accuracies in NB \\
\hline Heart & Cheung, & 2001 & $81.48 \%$ \\
\hline Heart & Andreeva, P & 2006 & $78.56 \%$ \\
\hline BC & Bellaachia et al & 2006 & $84.50 \%$ \\
\hline Heart & Palaniappan, et al. & 2007 & $95.00 \%$ \\
\hline Heart & Sitar-Taut et al. & 2009 & $62.03 \%$ \\
\hline Heart & Asha Rajkumar et al & 2010 & $52.33 \%$ \\
\hline Heart & Jyoti Soni & 2011 & $96.50 \%$ \\
\hline Heart & Akhil jabbar et al & 2012 & $76.00 \%$ \\
\hline Heart & Abhishek Taneja & 2013 & $91.96 \%$ \\
\hline Lung Cancer & V. Krishnaiah et al. & 2013 & $84.14 \%$ \\
\hline
\end{tabular}

Navies Bayes is the most common technique that is used in data mining. It gives maximum accuracy of $96.5 \%$ in curing heart patients as shown in Figure 3.

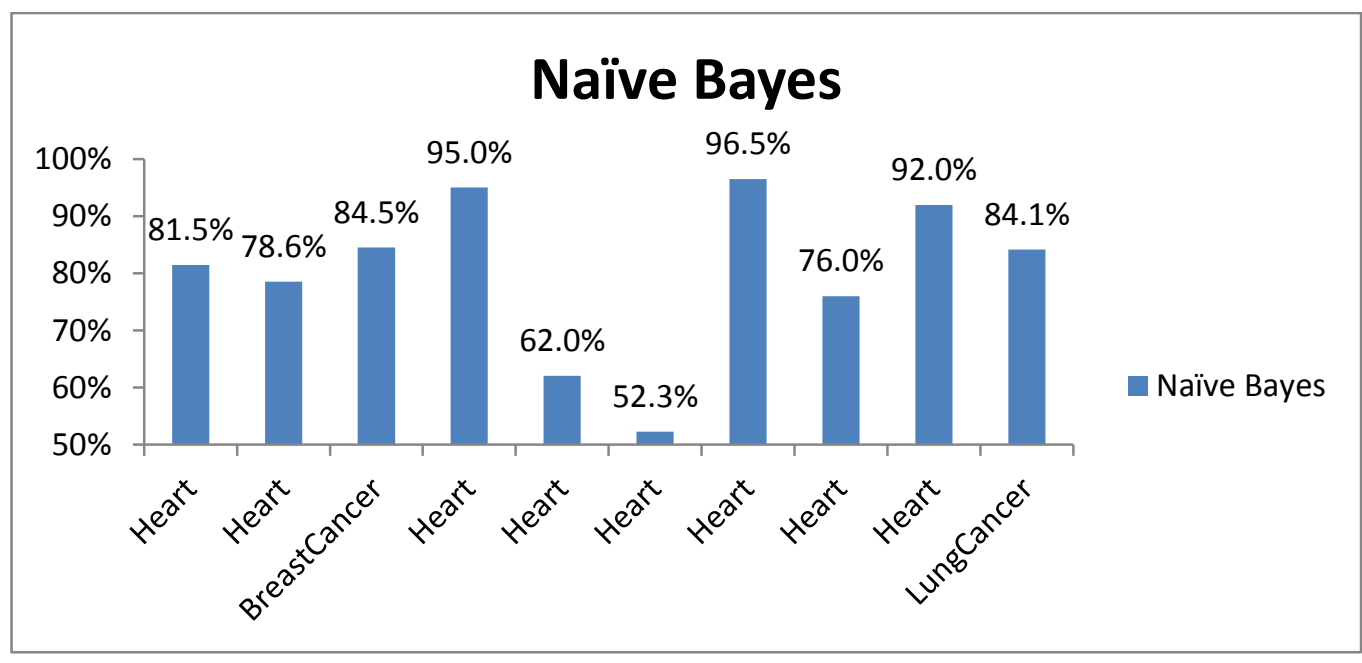

Figure 3. Comparison of Various Diseases on Naïve Bayes Technique

Naïve bayes is widely used technique in prediction of various diseases and has the maximum accuracy of $96.5 \%$.

\section{Risk Factors Involved in Healthcare Systems}

Although scientists do not know the exact causes of some medical problems, they do know some of the risk factors that increase the likelihood of a disease in human beings. Table 9 highlights some of the major risk factors involved in the diagnosis of medical diseases.

\section{Table 9. Risk Factors involved for the Prediction of Various Medical Diseases}

\begin{tabular}{|l|l|l|}
\hline S.No. & Disease & Risk factors \\
\hline 1. & Lung cancer & $\begin{array}{l}\text { Smoking (beedi, hookah or cigarette) or second hand smoke, } \\
\text { High dose of ionizing radiation, Air pollution, Insufficient } \\
\text { consumption of fruits \& vegetables [8] }\end{array}$ \\
\hline
\end{tabular}




\begin{tabular}{|l|l|l|}
\hline 2 & Skin cancer & $\begin{array}{l}\text { UV light, smoking, large no. of moles on the skin, family history } \\
\text { of skin cancer, work outdoors [23] }\end{array}$ \\
\hline 3 & Breast cancer & $\begin{array}{l}\text { Drinking alcohol, tobacco, passive smoking, obesity and lack of } \\
\text { exercise, night shift work.[4] }\end{array}$ \\
\hline 4 & Heart disease & $\begin{array}{l}\text { Smoking, Diabetes, high blood pressure, high cholesterol, low } \\
\text { cholesterol, not getting enough physical activity and obesity. [14] }\end{array}$ \\
\hline 5 & $\begin{array}{l}\text { Kidney } \\
\text { failure }\end{array}$ & $\begin{array}{l}\text { Diabetes, High blood pressure, Heart disease, Smoking, Obesity, } \\
\text { High cholesterol, Family history of kidney disease [28] }\end{array}$ \\
\hline 6 & $\begin{array}{l}\text { Liver } \\
\text { Disorder }\end{array}$ & $\begin{array}{l}\text { Excessive alcohol consumption, Obesity, Diabetes, Tobacco use, } \\
\text { Cirrhosis, Hereditary, Exposure to aflatoxins, viruses(primarily } \\
\text { hepatitis A [HAV], hepatitis B [HBV], or hepatitis C [HCV]) [21] }\end{array}$ \\
\hline
\end{tabular}

The risk factors of various diseases conclude towards the common risk factor i.e. intake of drugs that leads to every hazardous diseases like cardiovascular disease, cancer, Lungs and kidney malfunction and many more. Drug abuse may trigger or exacerbate mental disorders, anxiety, stress, depressions and even death.

\section{Effect on health of drug users}

A drug is a social problem these days and youth is in the falling in trap of drugs. There is need to aware the youth about the common problems with drug abusers.

\section{Common Problems with drug abusers are:-}

- HIV, Hepatitis and Other Infectious Diseases

- Cardiovascular Effects

- Respiratory Effects

- Gastrointestinal Effects

- Musculoskeletal Effects

- Kidney Damage

- Liver Damage

- Neurological Effects

- Mental Health Effects

- Hormonal Effects

- Cancer

- Prenatal Effects

- Other Health Effects

- Mortality

The research work mainly focused on knowing the major motive for commencement and indulging the youth in drugs. The research work is of great help for analyzing various factors for booming situation of drugs. The system is of great relevance to the user in detection of the various factors related to drug addiction which will help in providing the correct medication about him/her and will help in saving his precious human live. No such work is done in this direction.

\section{Parameters Selected for Drug Addicted People}

21 parameters have been selected that are most important. The author has performed the Experiments on a real data set to study the impact of constraints and the elimination of unreliable rules with validation on the test set. Table 10 specifies the values with respect to parameters. 
Table 10. Parameters for Drug Addicted People

\begin{tabular}{|l|l|}
\hline Parameters & Values \\
\hline Sex & Male, Female \\
\hline Age & upto20,21_40,41_60,above60 \\
\hline Residence & urban, rural \\
\hline Type of locality & slum, private, govt. approved \\
\hline Marital Status & Married, Unmarried, Divorced \\
\hline Type of family & Joint, Nuclear \\
\hline Education & $\begin{array}{l}\text { illiterate, Primary, Less than primary, Secondary, graduation, } \\
\text { above graduation }\end{array}$ \\
\hline Occupation & unemployed, student, job, business \\
\hline Age of Initiation & upto20, above20 \\
\hline $\begin{array}{l}\text { Duration of substance } \\
\text { abuse }\end{array}$ & $1 \_10$ yrs,11_20 yrs ,above 20yrs \\
\hline Family Income & Rs( upto5000,6_10000,11_25000,26_40000, above40000 ) \\
\hline House & Own, Rented \\
\hline $\begin{array}{l}\text { Who prompted you for } \\
\text { drugs }\end{array}$ & internal (personal) factors, external factors \\
\hline $\begin{array}{l}\text { In which company it was } \\
\text { taken }\end{array}$ & $\begin{array}{l}\text { internal (house, shop, etc) place, external place (marriage, } \\
\text { schools, colleges, etc) }\end{array}$ \\
\hline Family history of drugs & Yes, No \\
\hline $\begin{array}{l}\text { Daily expenditure on } \\
\text { drugs }\end{array}$ & Rs (1_200,201_500,501_1000, above1000) \\
\hline $\begin{array}{l}\text { In case no money for } \\
\text { drugs }\end{array}$ & Yes(stealing, theft, borrow, etc), No \\
\hline $\begin{array}{l}\text { Did you sell any house } \\
\text { hold articles if you don't } \\
\text { have money for buying } \\
\text { drugs }\end{array}$ & Yes, No \\
\hline $\begin{array}{l}\text { Any accident while } \\
\text { having drugs }\end{array}$ & Yes (1time or more), No \\
\hline Conflict with law \\
\hline $\begin{array}{l}\text { Anyone helped you in } \\
\text { getting rid of this drug } \\
\text { taking problem }\end{array}$ & Yes (1time or more), No \\
\hline
\end{tabular}

\section{Proposed Methodology using WEKA Tool}

To evaluate the performance of our approach, a data set is surveyed with 40 patients admitted at Ludhiana drug de-addiction centre. Then data is loaded into the WEKA tool, after the dataset has been loaded. Naïve Bayes, Decision tress (J48), Multilayer perceptron (MLP), Logistic regression are selected. Data is then cross validated using performance classifier measure, the results and performance of each algorithm is then compared to each other. Figure 4 reveals the working of WEKA tool. 


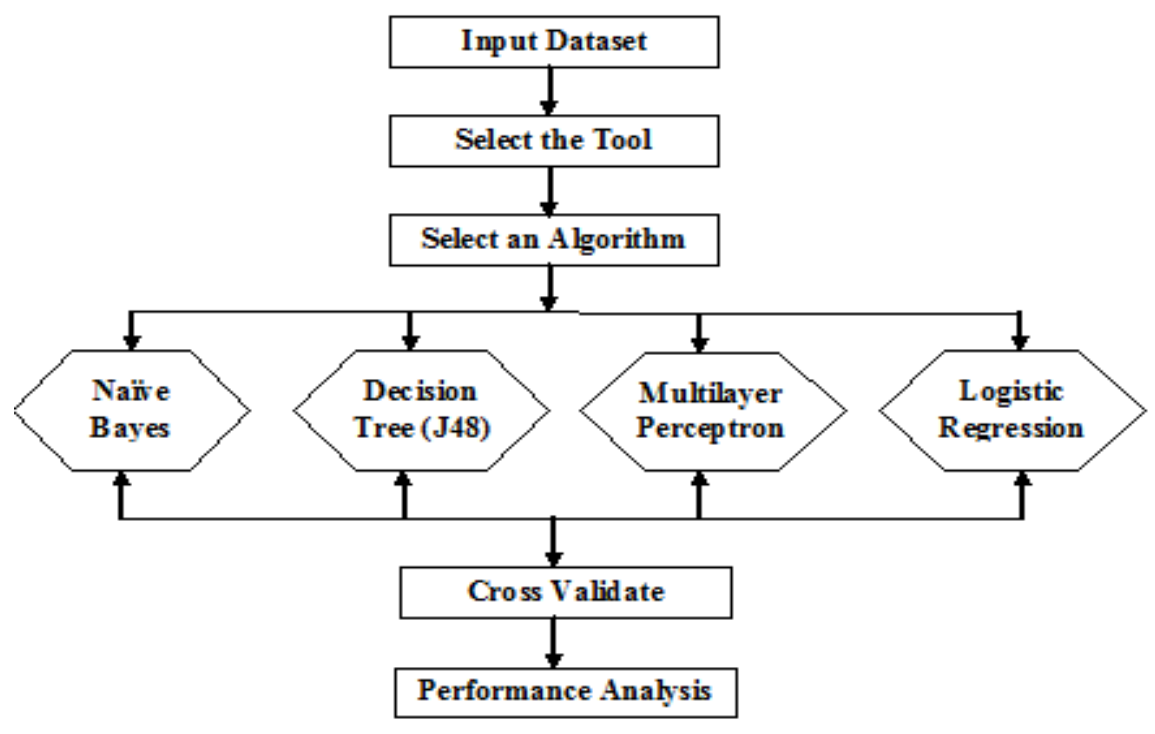

Figure 4. Working of WEKA Tool

\section{Results}

Accuracy is major constraint in medical field which fails with minor fluctuations. More the accuracy better are the results. Day by day more research work is going to achieve results with high accuracy and less effort to save precious human life before the problem occurs. Accuracy is measured in terms of correctly classified instances. Table 11 exemplifies data mining techniques with accuracy or correctly/ incorrectly classified techniques.

Table 11. Comparison of Various Data Mining Techniques

\begin{tabular}{|l|c|c|}
\hline Algorithm & $\begin{array}{l}\text { Correctly Classified } \\
\text { Instances }\end{array}$ & $\begin{array}{l}\text { Incorrectly Classified } \\
\text { Instances }\end{array}$ \\
\hline Navie Bayes & $80 \%$ & $20 \%$ \\
\hline J48 (DTrees) & $95 \%$ & $5 \%$ \\
\hline Multilayer Perceptron(MLP) & $90 \%$ & $10 \%$ \\
\hline Logistic Regression & $87.50 \%$ & $12.50 \%$ \\
\hline
\end{tabular}

Decision trees give the maximum accuracy of $95 \%$ which respect to age of initiation parameter i.e., $\mathrm{J} 48$ gives maximum accuracy of $95 \%$ among the affected patients started using their drug usage at below $20 \mathrm{yrs}$ of age. The Statistics are disclosed in Figure 5 exposing the $\mathrm{J} 48$ having $95 \%$ of accuracy. 


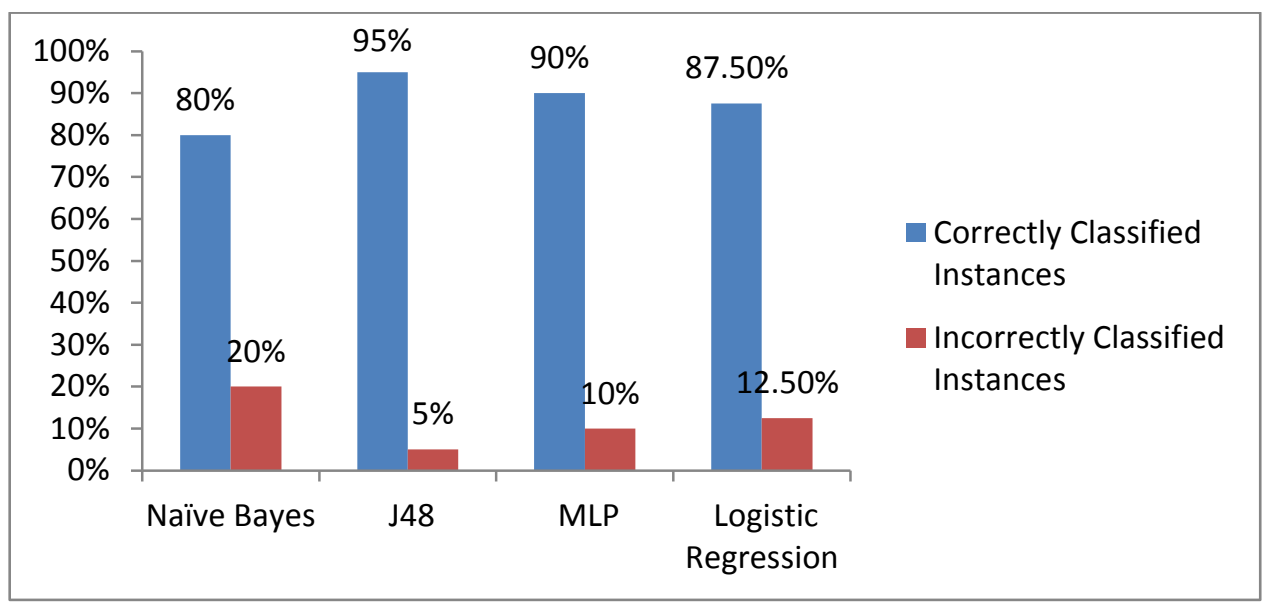

Figure 5. Analysis of Data Mining Techniques

\section{Conclusion}

Applying data mining in the medical field is an incredibly challenging mission due to the idiosyncrasies of the medical profession. It characterizes widespread process that demands thorough understanding of needs of the healthcare organizations. Knowledge gained with the use of techniques of data mining can be used to make successful decisions that will improve success of healthcare organization and health of the patients. This review of data mining applications in medicine and public health has endowed us with an overview of current practices and challenges. Health care organizations and agencies could come across into these applications to find ideas on how to dig out knowledge from their own database systems. Data mining requires suitable technology and analytical techniques, as well as systems for reporting and tracking which can facilitate measuring of results. The available raw medical data are widely distributed, different and voluminous by nature that must be collected and stored in data warehouses in organized form.

Healthcare institutions that use data mining applications have the possibility to predict future requests, needs, desires and conditions of the patients and to make adequate and optimal decisions about their treatments. Thus, there exist promising techniques to predict and forecast the medical diseases with high accuracy and low cost With the future development of information communication technologies, data mining will achieve its full potential in the discovery of knowledge hidden in the medical data so as to simultaneously retrieve the information and minimize the efforts of an expert system for various diseases under consideration. Within the issue of knowledge integrity assessment, two biggest challenges are: (1) How to develop efficient algorithms for comparing content of two knowledge versions (before and after). This challenge demands development of efficient algorithms and data structures for evaluation of knowledge integrity in the data set; and (2) How to develop algorithms for evaluating the influence of particular data modifications on statistical importance of individual patterns that are collected with the help of common classes of data mining algorithm.

Algorithms that measure the influence that modifications of data values have on discovered statistical importance of patterns are being developed, although it would be impossible to develop a universal measure for all data mining algorithms. Even if data mining results are credible, convincing the health practitioners to change their habits based on evidence may be a bigger problem. Data mining in healthcare can be limited in data access, since the raw inputs for data mining frequently exist in different settings and systems, like administrations, clinics, laboratories etc. Therefore, data must be collected and integrated before data mining can take place. Building of data warehouse before data mining begins can be a very expensive and time consuming process. Data mining project 
can fail from numerous reasons, like lack of managerial support, inadequate data mining expertise etc. Healthcare organizations that develop data mining must use big investment resources, especially time, effort and money.

Survey of data mining in medical field outputs towards the common risk factor i.e. drug addiction. Many people do not know when they get addicted to drugs. Drug is a brain eater. Everyday a new stories comes disastrous effects of drugs into the human life. Long term drug usage affects the brain and other important organs of the body. So, data mining is preferred for prediction that gives results in terms of accuracy which is the major concern in medical field.

Yes Data mining really provide an efficient way to extract the required clinical information from voluminous, raw and heterogeneous data. Decision trees, Neural Networks, Logistic regression, Naïve Bayes etc are the promising techniques that predict and forecast the medical diseases with high accuracy and low cost. Various issues and challenges in data mining applied to medical field are focusing on survival of the unaware affected person by predicting the cause of disease at earlier stage. Drug addiction using WEKA has been shown and it brings into light that majority of drug abusers started abusing drugs at age below 20yrs.It is to make aware the druggist about the various diseases that are caused with heavy or long term intake of drugs in their life. So, to make an expert system that will awake the youth about precarious use of drugs and also alert the affected person.

\section{Future Work}

Our future work will involve the amalgamation of the various specified algorithms to augment the accuracy so that the diagnosis can develop into more accurate in case of imperceptibly identified data sets. The research work mainly focused on knowing the major motive for commencement and indulging the youth in drugs. Ongoing efforts are geared towards increasing the size of data set. The research work is of great help for analyzing various factors for booming situation of drugs. The system is of great relevance to the user in detection of the various factors related to drug addiction which will help in providing the correct medication about him/her and will help in saving his precious human live.

\section{References}

[1] Joseph D. Bronzino, Ralph A. Morelli, John W. Goethe," Design of an expert system for monitoring drug treatment in a psychiatric hospital", Computer-Based Medical Systems (CBMS), Fourth Annual IEEE Symposium CBMS pp. 219-225, 1991.

[2] Neat, Gregory W. ; Rensselaer Polytech. Inst., Troy, NY, USA ; Kaufman, H. ; Roy, Rob J. ,” Expert adaptive control for drug delivery systems", Control Systems Magazine, IEEE, Vol. 9 , No. 4, pp. 20 24, June 1989.

[3] Gil, A.G., Wagner, E.F., Vega, W.A. Acculturation, familism, and alcohol use among Latino adolescent males (Longitudinal relations) . J Community Psychol (john wiley \& sons) Vol. 28, pp. 443-458, 2000.

[4] Borsari, B., \& Carey, K. (2003). Descriptive and injunctive norms in college drinking: A meta-analytic integration. Journal of Studies on Alcohol, Vol. 64, pp. 331-341, 2003.

[5] D. Delen, G. Walker, and A. Kadam, Predicting breast cancer survivability: a comparison of three data mining methods, Artificial Intelligence in Medicine (Elsevier), vol. 34, no. 2, pp. 113-127, 2005.

[6] A. Bellaachia and E. Guven," Predicting breast cancer survivability using data mining techniques", In Proceedings of Ninth Workshop on Mining Scientific and Engineering Datasets in conjunction with the Sixth SIAM International Conference on Data Mining(SDM 2006), 2006.

[7] Rhew, I.C. Drug use and risk among youth in different rural contexts. Health Place (Elsevier). Vol. 17, pp. 775-783, 2011.

[8] Shweta Kharya," Using data mining techniques for diagnosis and prognosis of cancer disease", International Journal of Computer Science, Engineering and Information Technology (IJCSEIT), Vol.2, No.2, April 2012.

[9] Angelina Pilatti, Juan Carlos Godoy, Silvina Brussino, Ricardo Marcos Pautassi,” Underage drinking: Prevalence and risk factors associated with drinking experiences among Argentinean children", Alcohol( Elsevier), Vol. 47, pp. 323-331, 2013. 
[10] Naresh Nebhinani, Shubh M Singh, Gourav Gupta," Demographic and clinical profile of substance abusing women seeking treatment at a de-addiction center in north India," Industrial Psychiatry journal, Vol. 22, 2013.

[11] Eduardo López-Caneda, Socorro Rodríguez Holguín, Montserrat Corral, Sonia Doallo, Fernando Cadaveira, Evolution of the binge drinking pattern in college students: Neurophysiological correlates, Alcohol (Elsevier) Vol. 48, 2014.

[12] Taisia Huckle, and Karl Parker, Long-Term Impact on Alcohol-Involved Crashes of Lowering the Minimum Purchase Age in New Zealand, American Journal of Public Health, Vol. 104, pp.10871091,June 2014.

[13] G. Ravi Kumar, Dr. G. A. Ramachandra, K.Nagamani,” An Efficient Prediction of Breast Cancer Data using Data Mining Techniques", International Journal of Innovations in Engineering and Technology (IJIET),Vol. 2 ,No. 4, pp139-144, August 2013.

[14] Kawsar Ahmed, Abdullah Al Emran, Tasnuba Jesmin, Roushney Fatima Mukti,Md Zamilur Rahman, Farzana Ahmed," Early Detection of Lung Cancer Risk Using Data Mining”, Asian Pacific Journal of Cancer Prevention, Vol. 14,pp. 595-598,2013.

[15] V.Krishnaiah "Diagnosis of Lung Cancer Prediction System Using Data Mining Classification Techniques", International Journal of Computer Science and Information Technologies (IJCSIT), Vol. 4, No. 1 , pp. $39-45,2013$.

[16] Asha Rajkumar and B. Sophia Reena, "Diagnosis Of Heart Disease Using Data mining Algorithm" , Global Journal of Computer Science and Technology, Vol. 10, No. 10, pp. 38 - 43, 2010

[17] M.Anbarasi, E. Anupriya, N.CH.S.N.Iyengar, Enhanced Preditction of Heart Disease with Feature Subset Selection using Genetic Algorithm. International Journal of Engineering Science and Technology,Vol. 2, No.10,pp. 5370-5376, 2010.

[18] M. Akhil Jabbar, Bulusu Lakshmana Deekshatulu, Priti Chandra," Heart Disease Prediction System using Associative Classification and Genetic Algorithm", International Conference on Emerging Trends in Electrical, Electronics and Communication Technologies(ICECIT), 2012.

[19] Mai Shouman, Tim Turner, Rob Stocker, "Using Data Mining Techniques In Heart Disease Diagnosis And Treatment ",Proceedings in Japan-Egypt Conference on Electronics, Communications and Computers,IEEE,Vol.2 pp.174-177,2012.

[20] Abhishek taneja," Heart Disease Prediction System Using Data Mining Techniques", Oriental journal of Computer science \& technology, Vol. 6, No. 4: pp. 457-466, December 2013.

[21] V. Chauraisa and S. Pal, "Data Mining Approach to Detect Heart Diseases", International Journal of Advanced Computer Science and Information Technology (IJACSIT), Vol. 2, No. 4, pp 56-66, 2013.

[22] S.J Gnanasoundhari, G.Visalatchi, Dr.M.Balamurugan," A Survey on Heart Disease Prediction System Using Data Mining Techniques", International Journal of Computer Science and Mobile Applications, Vol. 2 No. 2, pp. 72-77, February- 2014.

[23] D.S. Kumar, G. Sathyadevi, S. Sivanesh,Decision support system for medical diagnosis using data mining, Journal of Computer Science, 8 (3) (2011), pp. 147-153

[24] Rajesh K \& Sangeetha V," Application of data mining methods and techniques for diabetes diagnosis", International journal of engineering and innovative technology, Vol. 2. Issue 3, 2012.

[25] Vikram Kumar Gupta , Paramjeet Kaur, Gurmeet Singh, Amanpreet Kaur, B. S. Sidhu," A study of profile of patients admitted in the drug de-addiction centers in the state of Punjab", International Journal of Research in Health Sciences, Vol. 1, Issue-2, 2014.

[26] DD Kaladhar, KA Rayavarapu, and Varahalarao Vadlapudi," Statistical and Data Mining Aspects on Kidney Stones: A Systematic Review and Meta-analysis Journal of Biometrics and Biostatistics", Vol. 1, No. 12, pp. 1-5, 2012.

[27] K.R.Lakshmi, Y.Nagesh and M.VeeraKrishna, "Performance comparison of three data mining techniques for predicting kidney disease survivability", International Journal of Advances in Engineering \& Technology, Vol. 7, Issue 1, pp. 242-254, March 2014.

[28] S.F. Shazmeen, M.M.A. Baig, and M.R. Pawar, "Performance Evaluation of Different Data Mining Classification Algorithm and Predictive Analysis," Journal of Computer Engineering, Vol. 10, No. 6, pp. 01-06, 2013.

[29] Jyoti Soni ,Ujma Ansari, Dipesh Sharma, Sunita Soni," Predictive Data Mining for Medical Diagnosis, An Overview of Heart Disease Prediction", International Journal of Computer Applications (0975 8887), Vol. 17, No. 8, March 2011.

[30] Kawsar Ahmed,Tasnuba Jesmin,Md. Zamilur Rahman:”Early Prevention and Detection of Skin Cancer Risk using Data Mining”, .International Journal of Computer ,Vol. 62 ,No. 4, pp. 1-6, 2013

[31] A. Laribi, S. A. Laribi," An Intelligent System to Facilitate the Diagnosis of Adverse Drug Reactions", IEEE International Conference on Tools with Artificial Intelligence (ICTAI), pp. 661-666, 1994

[32] Andreeva, P., "Data Modeling and Specific Rule Generation via Data Mining Techniques", International Conference on Computer Systems and Technologies - CompSysTech, 2006.

[33] Sellappan Palaniappan, Rafiah Awang "Intelligent Heart Disease Prediction System Using Data Mining Techniques" International Conference on Computer Systems and Applications, IEEE/ACS, pp.108-115, AICCSA April 2008. 
[34] Srinivas, Rao and Govardhan, "Analysis of coronary heart disease and prediction of heart attack in coal mining regions using data mining techniques", In IEEE Proceedings of the 5th International Conference on Computer Science and Education, Hefei, China, pp. 1344-1349, 2010.

[35] Andrew Kusiak, Bradley Dixon, Shital C. Shah," Predicting survival time for kidney dialysis patients: a data mining approach.",Comp. in Bio. and Med. 35(4): pp.311-327, 2005.

[36] Annis, H. M., \& Davis, C. S," Relapse prevention. In R. K. Hester \& W. R. Miller (Eds.)", Handbook of alcoholism treatment approaches: Alternative approaches pp. 170 - 182. New York: Pergamon Press, 1989.

[37] Naresh Nebhinani, Shubh M Singh, Gourav Gupta," Demographic and clinical profile of substance abusing women seeking treatment at a de-addiction center in north India," Industrial Psychiatry journal, Vol. 22, Issue 1, 2013.

[38] Indiver Kalra, Pir Dutt Bansal," Sociodemographic Profile and Pattern of Drug abuse among Patients Presenting to a Deaddiction Centre in rural area of Punjab", delhi psychiatry journal, Vol. 15, No.2, 2012.

[39] Angelina Pilatti , Juan Carlos Godoy, Silvina Brussino , Ricardo Marcos Pautassi,” Underage drinking: Prevalence and risk factors associated with drinking experiences among Argentinean children", Alcohol( Elsevier),Vol. 47, Issue. 4, pp. 323-331,2013.

[40] C. Duff,"Party drugs and party people: Examining the "normalisation" of recreational drug use in Melbourne, Australia”, International Journal of Drug Policy (Elsevier), Vol. 16, Issue. 3, pp. 161-170, 2005.

[41] G.Sathyadevi, "Application of CART Algorithm in Hepatitis Disease Diagnosis", Recent Trends in Information Technology (ICRTIT), International Conference IEEE, pp. 1283-1287, 2011.

[42] Yan, H., et al., Development of a decision support system for heart disease diagnosis using multilayer perceptron. Proceedings of the 2003 International Symposium on, 2003. vol.5: p. pp. 709-712.

[43] Sitar-Taut, V.A., et al., Using machine learning algorithms in cardiovascular disease risk evaluation. Journal of Applied Computer Science \& Mathematics, 2009.

[44] M. De Beule, E. Maes, O. De Winter, W. Vanlaere, R. Van Impe, Artificial neural networks and risk stratification: A promising combination Mathematical and Computer Modelling (Elsevier), 46 (2007), pp. 88-94

[45] C. L. Chang and C. H. Chen, "Applying decision tree and neural network to increase quality of dermatologic diagnosis", Expert Systems with Applications, Elsevier, vol. 36, (2009), pp. 4035-4041.

[46] Tu, M.C., D. Shin, and D. Shin, Effective Diagnosis of Heart Disease through Bagging Approach. Biomedical Engineering and Informatics, IEEE, 2009.

[47] Tanawut Tantimongcolwat, Thanakorn Naenna, Chartchalerm Isarankura-Na-Ayudhya , Mark J. Embrechts , Virapong Prachayasittikul, Identification of ischemic heart disease via machine learning analysis on magnetocardiograms, Computers in Biology and Medicine (Elsevier), v.38 n.7, p.817-825, July, 2008

[48] A. Hara and T. Ichimura, "Data Mining by Soft Computing Methods for the Coronary Heart Disease Database", Fourth International Workshop on Computational Intelligence \& Application, IEEE SMC Hiroshima Chapter, Hiroshima University, Japan, (2008) December 10-11.

[49] H.A. Guvenir and N. Emeksiz, "An expert system for the differential diagnosis of erythemato-squamous diseases," Expert Systems with Applications (Elsevier), Vol. 18, Issue. 1, pp. 43-49, 2000.

[50] C. C., Lopes, H. S., Freitas, A. A., Bojarczuk, "Data Mining with Constrained-Syntax Genetic Programming: Applications in Medical Data Set," in Data Analysis in Medicine and Pharmacology (IDAMAP-2001), a Workshop at Medinfo-2001, London, UK, 2001.

[51] K. Polat and S. Gunes, "A novel hybrid intelligent method based on C4.5 decision tree classifier and one-against-all approach for multi-class classification problems," Expert Systems with Applications (Elsevier), vol. 36, no. 2, pp. 1587-1592, 2009.

[52] E. D. Ubeyli and E. Dogdu, "Automatic Detection of Erythemato-Squamous Diseases Using k-Means Clustering," Journal of Medical Systems (Springer), Vol. 34, pp. 179-184, 2010.

[53] J. Xie and Ch. Wang, "Using support vector machines with a novel hybrid feature selection method for diagnosis of erythemato-squamous diseases," Expert Systems with Applications, vol. 38, no. 5, pp. 5809-5815, 2011.

[54] Kumar, D. S., Sathyadevi, G. and Sivanesh, S.," Decision Support System for Medical Diagnosis Using Data Mining”, IJCSI International Journal of Computer Science Issues, Vol. 8, No. 1, 2011. 
International Journal of Energy, Information and Communications Vol.6, Issue 4 (2015) 